\title{
Prevention of Graft Rejection by Donor Type II CD8+ T Cells (Tc2 Cells) Is Not Sufficient to Improve Engraftment in Fetal Transplantation
}

\author{
Jeng-Chang Chen ${ }^{a, b}$ Ming-Ling Chang ${ }^{c, d}$ Hanmin Lee $^{a}$ \\ Marcus O. Muench ${ }^{\mathrm{e}}$ \\ aFetal Treatment Center, Department of Surgery, University of California, San Francisco, Calif., USA; \\ bDepartment of Surgery, Chang Gung Children's Hospital, Taoyuan, Taiwan; 'Liver Center, Department of Medicine, \\ University of California, San Francisco, Calif., USA; dDepartment of Hepatology, Chang Gung Memorial Hospital, \\ Taoyuan, Taiwan; ' Department of Laboratory Medicine, University of California, San Francisco, Calif., USA
}

\section{Key Words}

Cytotoxic T cells · Fetal transplantation - Peritoneal

chimerism $\cdot$ Immune tolerance

\begin{abstract}
Objectives: $\mathrm{Tc} 2$ cells, a subset of $\mathrm{CD} 8^{+} \mathrm{T}$ cells, are able to facilitate engraftment in a murine model of postnatal allogeneic bone marrow transplantation. The purpose of this study was to evaluate whether Tc2 cells could improve engraftment in fetal transplantation. Methods: Gestational day $13 \mathrm{C} 57 \mathrm{BL} / 6\left(\mathrm{H}-2^{\mathrm{b}}\right)$ fetal mice were used as recipients, adult $\mathrm{B} \mathrm{D} 2 \mathrm{~F}_{1}$ mice $(\mathrm{C} 57 \mathrm{BL} / 6 \times \mathrm{DBA} / 2$, $\mathrm{H}-2^{\mathrm{b} / \mathrm{d}}$ ) as donors, and splenocytes from $\mathrm{B} \mathrm{C} 3 \mathrm{~F}_{1}$ (C57BL/6 $\times \mathrm{C} 3 \mathrm{H} / \mathrm{He}, \mathrm{H}-2^{\mathrm{b} / \mathrm{k}}$ ) mice were used as stimulators in cultures used to generate the Tc2 cells from B6D2F 1 mice. Peripheral blood chimerism was examined monthly for 3 months. Thereafter, recipients were sacrificed to evaluate the levels of peritoneal, splenic and bone marrow chimerism. The T-cell responses of recipient splenocytes to
\end{abstract}

J.-C.C. and M.-L.C. were scholars visiting the University of California, San Francisco, Calif. from Taiwan during the period of October 16, 2000 to October 15, 2002.

\section{KARGER}

Fax +41613061234 E-Mail karger@karger.ch www.karger.com

\section{(C) 2005 S. Karger AG, Basel}

Accessible online at: www. karger.com/fdt cells of host origin were measured as a proliferative response in mixed lymphocyte cultures. Results: Low levels of peripheral blood cell chimerism $(<0.3 \%)$ were observed at 1 month of age, which declined further by 3 months of age. The levels of donor cells in the spleen, bone marrow and peritoneal cavity were usually not more than $0.05 \%$. The peritoneal cavity tended to have higher levels of donor cells with 1 recipient sustaining as high as $25.03 \%$ at the age of 3 months. Higher peritoneal chimerism correlated with a lower donor-specific T-cell response. Conclusions: Transplantation of Tc2 cells was insufficient to improve bone marrow engraftment in utero, suggesting that graft rejection is not the major barrier to successful in utero transplantation. Donor cells can persist in the peritoneal cavity and might play an important role in inducing immune tolerance in fetuses.

Copyright $\odot 2005$ S. Karger AG, Basel

\section{Introduction}

Despite considerable promise as an approach for the management of congenital hematological and metabolic disorders, in utero transplantation (IUT) of hematopoietic stem cells (HSCs) faces obstacles that limit the effec-

Marcus O. Muench, PhD

University of California at San Francisco

513 Parnassus Ave, Room HSW-901B

San Francisco, CA 94143-0793 (USA)

Tel. +1 415476 8420, Fax +1 415476 2956, E-Mail muench@itsa.ucsf.edu 
tiveness of this form of therapy [1-3]. Although IUT has produced notable levels of hematopoietic chimerism in a sheep model [4], minimal or no engraftment has been observed in most murine models [5-9]. Moreover, clinical experience with IUT has yielded little or no engraftment with the exception of transplants made in fetuses suffering from certain immunodeficiencies [1,2]. A number of lines of evidence point toward a lack of space in the hematopoietic tissues for donor HSCs to engraft as one possible reason for poor outcomes $[1,10]$. Despite the immaturity of the fetal immune system, NK cells and even $T$ cells are present in the late first trimester fetus and may further prevent donor cell engraftment [11]. Better defining the barriers to HSC engraftment in utero is the key to improving IUT, to treat a wider range of birth defects.

In postnatal bone marrow transplantation (BMT), $\mathrm{T}$ lymphocytes present in the marrow inoculum can abrogate graft rejection but often at the expense of graft-versus-host disease (GVHD) [12-16]. Donor T cells have also been found to facilitate IUT [17-19]. It has been suggested that the graft-versus-host effect of donor T cells can help to generate homing spaces so that donor HSCs stand a better chance to engraft [19]. However, the transplantation of alloreactive T cells also presents the risk of GVHD [18]. Further study has indicated that the $\mathrm{CD}^{+}$subset of $\mathrm{T}$ cells appear to be responsible for abrogating graft rejection as well as generating GVHD [20-24]. It is recognized that cytotoxic $\mathrm{CD} 8^{+} \mathrm{T}$ cells exist in polarized cytokine secreting subsets, defined as Tc1 and Tc2 cells [25, 26]. The Tc1 subset secretes interleukin (IL)-2 and interferon- $\gamma($ IFN- $\gamma)$, whereas the Tc2 subset secretes IL-4, IL-5 and IL-10. The type I cytokines induce a pro-inflammatory immune reaction, whereas the type II cytokines exert an anti-inflammatory effect [27]. The balance between the two subsets may play an important role in determining the nature of the systemic immune response to a particular pathogen. Recently, it has been recognized that Tc2 cells are able to dramatically facilitate engraftment with reduced GVHD in a murine model of postnatal allogeneic BMT [27-30]. The current study was aimed at evaluating whether IUT of the Tc2 subset could facilitate HSC engraftment in mice.

\section{Materials and Methods}

\section{Mice Used}

The same $\mathrm{F}_{1}$-into-parent transplantation model was used as reported by Fowler et al. [28] in their study of the role of Tc2 cells in adult allogeneic transplantation: C57BL/6 $\left(\mathrm{H}-2^{\mathrm{b}}\right)$ fetal mice were used as recipients, $\mathrm{B} 6 \mathrm{D} 2 \mathrm{~F}_{1}\left(\mathrm{C} 57 \mathrm{BL} / 6 \times \mathrm{DBA} / 2, \mathrm{H}-2^{\mathrm{b} / \mathrm{d}}\right)$ as donors, and splenocytes from $\mathrm{B} 6 \mathrm{C}_{3} \mathrm{~F}_{1}\left(\mathrm{C} 57 \mathrm{BL} / 6 \times \mathrm{C} 3 \mathrm{H} / \mathrm{He}, \mathrm{H}-2^{\mathrm{b} / \mathrm{k}}\right)$ mice were used as stimulators in cultures used for generating the Tc2 cells. $\mathrm{C} 57 \mathrm{BL} / 6$ and $\mathrm{B}_{6 \mathrm{C} 3 \mathrm{~F}_{1}}$ (8 weeks of age) mice were purchased from Charles River (Wilmington, Mass., USA) or Simonsen Laboratory (Gilroy, Calif., USA). B6D2F 1 (8-20 weeks of age) mice were either purchased, from the above companies, or obtained from a breeding program at Howard Hughes Medical Institute at University of California, San Francisco (UCSF). All animals were housed in the Animal Care Facility at UCSF in accordance with federal guidelines and with the approval of the UCSF Committee on Animal Research.

\section{Generation of Tc2 Cells}

Donor $\left(\mathrm{B} 6 \mathrm{D} 2 \mathrm{~F}_{1}\right)$ splenocytes were harvested by passage through $70-\mu \mathrm{m}$ cell strainers (Becton Dickinson \& Co., Franklin Lakes, N.J., USA) and depleted of red cells using ACK buffer, $\mathrm{pH}$ 7.2-7.4, consisting of $0.15 M \mathrm{NH}_{4} \mathrm{Cl}, 1.0 \mathrm{~m} M \mathrm{KHCO}_{3}$ and $0.1 \mathrm{~m} M \mathrm{Na}_{2}$ EDTA (Sigma Chemical Co., St. Louis, Mo., USA). The splenic leukocytes were treated with biotinylated anti-CD4, anti-CD19, anti-CD24, anti-MHC class II (I-A/I-E) and anti-Gr1 monoclonal antibodies (BD Biosciences, San Diego, Calif., USA). $\mathrm{CD}^{+} \mathrm{T}$ cells were then enriched by negative depletion using streptavidin-coated magnetic Dynabeads (Dynal Biotech Inc., Lake Success, N.Y., USA).

Tc2 cultures were performed as described by Fowler et al. [28] with minor modifications as suggested by Dr. Fowler [pers. commun., December 11, 2000]. Culture media consisted of RPMI 1640 supplemented with $10 \%$ heat-inactivated fetal bovine serum (Hyclone, Logan, Utah, USA), sodium pyruvate (1\%), non-essential amino acids $(1 \%), L$-glutamate $(0.5 \%)$, 2-mercaptoethanol $\left(5 \times 10^{-5}\right)$, penicillin $(50 \mathrm{U} / \mathrm{ml})$ and streptomycin $(50 \mu \mathrm{g} / \mathrm{ml})$ and N-acetylcysteine (Sigma Chemical Co.; $10 \mathrm{mmol} / \mathrm{l}, \mathrm{pH}$ adjusted to 7.2). The enriched $\mathrm{CD}^{+}$cells were suspended at $1 \times 10^{6}$ cells $/ \mathrm{ml}$ and cocultured, at a ratio of 1:5, with 3,000 cGy irradiated whole splenocytes from $\mathrm{B} 6 \mathrm{C}_{3} \mathrm{~F}_{1}$ mice. These $\mathrm{Tc} 2$ cultures received recombinant human (rh) IL-2 at 1,000 U/ml (R\&D Systems, Inc., Minneapolis, Minn., USA), rhIL-7 at $20 \mathrm{ng} / \mathrm{ml}$ (R\&D Systems) and recombinant murine IL-4 at 1,000 U/ml (PeproTech, Rocky Hill, N.J., USA) on day 0 . On day 2 , they were supplemented with rhIL-2 $(40 \mathrm{U} / \mathrm{ml})$ and rhIL-7 $(20 \mathrm{ng} / \mathrm{ml})$. On day 4 of culture, Tc2 flasks were harvested, brought to a concentration of $5 \times 10^{5}$ cells $/ \mathrm{ml}$, supplemented with rhIL-2 (40 U/ml) and rhIL-7 $(20 \mathrm{ng} / \mathrm{ml})$, and stimulated again with $3,000 \mathrm{cGy}$ irradiated $\mathrm{B} 6 \mathrm{C}_{3} \mathrm{~F}_{1}$ whole splenocytes at $1: 5$ ratio. On day 7, Tc2 cultures were harvested and centrifuged over a layer of NycoPrep 1.077A (Nycomed, Pharma AS, Oslo, Norway) to remove dead cells. The light-density cells were carefully transferred and resuspended in RPMI 1640 for flow cytometric evaluation and in utero injection.

For the comparison of secreted-cytokine profiles, Tc1 cells were generated using recombinant murine IL-12 (PeproTech) at $20 \mathrm{U} / \mathrm{ml}$ and recombinant human transforming growth factor- $\beta_{1}$ (R\&D Systems) at $10 \mathrm{ng} / \mathrm{ml}$, instead of IL-4, on day 0 [28].

\section{Flow Cytometric and Enzyme-Linked Immunosorbent Assay (ELISA) Evaluation of Tc2 Cells}

Aliquots of light-density $\mathrm{Tc} 2$ cells were suspended in culture supernatant, containing $0.01 \% \mathrm{NaN}_{3}$, from the hybridoma clone 2.4G2 (American Type Culture Collection, Manassas, Va., USA) that produces monoclonal antibody (mAb) against Fc $\gamma I I / F c \gamma I I I$ receptors. This supernatant was used to block non-antigen-specific binding of immunoglobulins. Cells were incubated with anti-CD4 
FITC (Caltag Laboratories, Burlingame, Calif., USA)/anti-CD8 PE (Caltag Laboratories) at $4{ }^{\circ} \mathrm{C}$ for $30 \mathrm{~min}$. Cells were also stained with anti-CD8 FITC (Caltag Laboratories)/anti-H-2K ${ }^{\mathrm{d}}$ PE (BD Biosciences) and anti-CD8 FITC/anti-CD69 PE (BD Biosciences). Three-color flow cytometry was performed on a FACScan (BD Biosciences) using propidium iodide (Molecular Probes, Eugene, Oreg., USA) staining to identify and exclude dead cells from the analysis. $2 \times 10^{4}$ live cells were acquired for analysis using CellQuest software (BD Biosciences).

For analysis of cytokine-secretion profiles, aliquots of light-density cells from $\mathrm{Tc} 2$ and $\mathrm{Tc} 1$ cultures were brought to a concentration of $5 \times 10^{5}$ cells $/ \mathrm{ml}$ in 24-well plates (Costar, Cambridge, Mass., USA) and stimulated with 3,000 cGy irradiated whole splenocytes of $\mathrm{B} 6 \mathrm{D} 2 \mathrm{~F}_{1}$ (syngeneic) mice and $\mathrm{B} 6 \mathrm{C}_{3} \mathrm{~F}_{1}$ (haplogeneic) mice, respectively, at a ratio of 1:5. Supernatants were harvested after $24 \mathrm{~h}$. These supernatants and those from day 7 cultures were tested for the presence of IFN- $\gamma$, IL-2, IL-4, IL- 5 and IL-10 by ELISA as recommended by the supplier, BD Biosciences/PharMingen.

\section{In utero Transplantation}

C57BL/6 females were caged with males in the afternoon and checked for vaginal plugs the following morning. The day when the plug was observed was designated as day 0 of the pregnancy.

Adult bone marrow cells (BMCs) from $\mathrm{B} 6 \mathrm{D} 2 \mathrm{~F}_{1}$ mice were harvested by flushing the tibias and femurs with phosphate buffer saline containing $0.3 \%$ bovine serum albumin (PBS/BSA) using a 26-gauge needle. Light-density BMCs were obtained by layering them over NycoPrep 1.077A and centrifuging at $600 \mathrm{~g}$ for $25 \mathrm{~min}$. Light-density BMCs was then depleted magnetically of $\mathrm{CD}^{+}$cells using biotinylated anti-CD3 mAb (BD Biosciences) and streptavidin-coated Dynabeads. All the donor cells were freshly injected within $3 \mathrm{~h}$ after preparation.

Time-dated pregnant mice (day 13) were subcutaneously anesthetized with ketamine $(100 \mathrm{mg} / \mathrm{kg})$ and xylazine $(10 \mathrm{mg} / \mathrm{kg})$. After vertical laparotomy to expose uteri, $1 \times 10^{6} \mathrm{~T}$-depleted BMCs and 3.5$5.0 \times 10^{5} \mathrm{Tc} 2$ cells in $5 \mu 1$ of RPMI 1640 were injected into the peritoneum of each fetus of a litter using a $60-\mu \mathrm{m}$ glass micropipette with a beveled tip. The abdomen was then closed using two layers of 4-O silk suture. After the operation, all mice were housed in an undisturbed room without bedding changes until the pups were 1 week old. Pups were weaned at 3 weeks of age.

\section{Analyses of Chimerism}

Peripheral blood was taken from a small incision at the tail tip at the ages of 1,2 and 3 months. Recipients were euthanized at the age of 3-5 months for obtaining splenocytes, BMCs and peritoneal cells. Peritoneal cells were first harvested by flushing the peritoneal cavity with $10 \mathrm{ml}$ PBS/BSA using a syringe with an 18-gauge needle. Subsequently, BMCs were harvested by flushing the tibias and femurs with PBS/BSA. At last, spleens were removed under sterile conditions, washed with PBS/BSA and dissociated by passage through a $70-\mu \mathrm{m}$ cell strainers. Samples were depleted of red cells using ACK buffer.

Prior to staining, cells were first incubated with culture supernatant containing anti-mouse $\mathrm{Fc} \gamma \mathrm{II} / \mathrm{Fc} \gamma \mathrm{III}$ antibody, and then stained with anti-H-2 $\mathrm{K}^{\mathrm{b}}$ FITC (BD Biosciences) and anti-H-2 $\mathrm{K}^{\mathrm{d}} \mathrm{PE}$. A negative control for each sample consisted of anti-H-2 $\mathrm{K}^{\mathrm{b}}$ FITC and mouse IgG2a PE (BD Biosciences) to define background staining. In some cases, cells were further stained with anti-H-2 $\mathrm{K}^{\mathrm{d}} \mathrm{PE}$ and either anti-CD4 FITC, anti-CD8 FITC, biotinylated anti-Ter119, biotiny- lated anti-CD19, biotinylated anti-Gr1 or biotinylated anti-F4/80 (Caltag Laboratories). FITC-conjugated streptavidin (Caltag Laboratories) was used in conjunction with the biotinylated mAbs. $1 \times 10^{5}$ events were acquired for analysis after gating out dead cells using propidium iodide. The levels of chimerism were derived by subtracting the percentage of background staining, defined by events positive for anti-H-2 $\mathrm{K}^{\mathrm{b}}$ FITC and mouse IgG2a PE, from the percentage of donor cells defined by events positive for anti-H-2 $\mathrm{K}^{\mathrm{b}}$ FITC and anti$\mathrm{H}-2 \mathrm{~K}^{\mathrm{d}} \mathrm{PE}$

\section{Mixed Lymphocyte Reaction (MLR)}

T-cell tolerance was evaluated by measuring MLRs using a flow cytometric method recently described [31]. Briefly, responder cells were red cell-depleted splenocytes from the recipients and stimulator cells were irradiated splenocytes from C57BL/6 (syngeneic), B6D2F $F_{1}$ (donor strain) and $\mathrm{FVB} / \mathrm{N}$ (third-party) mice. Splenocytes from untransplanted C57BL/6 mice were used as the control responders. Mixed lymphocyte cultures were harvested after 6 days. The number of reactive daughter $\mathrm{CD}^{+} \mathrm{T}$ cells generated was measured and compared for the experimental $\left(\mathrm{B} 6 \mathrm{D} 2 \mathrm{~F}_{1}\right)$, third-party $(\mathrm{FVB} / \mathrm{N})$ and control $(\mathrm{C} 57 \mathrm{BL} / 6)$ groups. A relative simulation index (SI) was calculated as follows: $\mathrm{SI}=\left(\mathrm{ME}_{\mathrm{BDF} 1}-\mathrm{ME}_{\mathrm{C} 57 \mathrm{BL} / 6}\right) /\left(\mathrm{ME}_{\mathrm{FVB} / \mathrm{N}}-\mathrm{ME}_{\mathrm{C} 57 \mathrm{BL} / 6}\right)$. In this equation, $\mathrm{ME}_{\mathrm{BDF} 1}, \mathrm{ME}_{\mathrm{C} 57 \mathrm{BL} / 6}$ and $\mathrm{ME}_{\mathrm{FVB} / \mathrm{N}}$ represent the mean number of events of recipient daughter $\mathrm{T}$ cells responsive to donor B6D2 $F_{1}$, syngeneic C57BL/6 and third-party FVB/N stimulators, respectively.

\section{Statistical Methods}

The non-parametric Wilcoxon signed ranks test was used to measure the significance of differences between two related samples of the peripheral blood. The independent-samples $t$ test was used to compare proliferation of $\mathrm{CD}^{+} \mathrm{T}$ cells in MLR stimulated by the different stimulator cells. Spearman correlation coefficient was used to test bivariate correlations between SI and donor cell levels in peripheral blood, spleen, bone marrow or peritoneal cavity. Results were considered significantly different when $\mathrm{p}<0.05$.

\section{Results}

\section{Characteristics of the Donor T Cells}

Cultured $\mathrm{CD} 8^{+} \mathrm{T}$ cells were shown to be enriched for Tc2 cells based on their cytokine secretion profile, which was compared to that of cultures optimized for Tc1 production (table 1). The Tc2 cell preparations contained more than $90 \% \mathrm{CD}^{+}$cells and less than $0.1 \%$ of $\mathrm{CD} 4^{+}$ cells. The activation status of Tc2 cells was assessed by CD69 expression. Before culture, $<3 \%$ of $\mathrm{CD} 8{ }^{+}$cells were $\mathrm{CD} 69^{+}$but after 7 days in culture $>90 \%$ of the $\mathrm{T}$ cells were CD69+(data not shown).

\section{Survival and Chimerism of the IUT Recipients}

Ninety-three fetuses from 10 pregnant mice were transplanted in utero with T-depleted BMCs and Tc2 cells. Ten recipients survived more than 1 month. How- 
Table 1. Cytokine secretion pattern of in vitro generated $\mathrm{Tc} 1$ and $\mathrm{Tc} 2 \mathrm{~T}$ cells

\begin{tabular}{llllll}
\hline & IFN- $\gamma$ & IL-2 & IL-4 & IL-5 & IL-10 \\
\hline Tc2 supernatant & & & & & \\
Day 7 & $3,731.2$ & ND & 58.6 & 471.0 & $1,109.3$ \\
Syngeneic re-stimulation & ND & ND & ND & ND & ND \\
Allogeneic re-stimulation & $4,190.4$ & ND & 13.3 & 96.7 & 73.3 \\
\hline Tc1 supernatant & & & & & \\
Day 7 & $6,328.6$ & ND & ND & ND & 181.4 \\
Syngeneic re-stimulation & ND & ND & ND & ND & ND \\
Allogeneic re-stimulation & $13,117.6$ & 5.5 & ND & ND & ND \\
\hline
\end{tabular}

Unit $=$ pg/ml; ND = none detected. Threshold values: IFN- $\gamma: 31.3$, IL-2: 3.1, IL-4: 7.8, IL-5: 15.6, IL-10: 31.3 . ever, 1 mouse died by the age of 2 months without any signs of GVHD such as changes in the appearance of the skin, weight loss or runting.

Donor cells were readily detected in the peripheral blood at 1 month after IUT (fig. 1a). Owing to the small sample sizes, the lineages represented by the donor cells were not analyzed. However, the light scatter properties of the donor cells suggested that the donor cells were comprised of both lymphoid and myeloid cells (fig. 1b). Chimerism levels in the blood were usually $<0.3 \%$ (fig. 2). However, 1 recipient had $4.56 \%$ of donor cells in the blood at 1 month of age, but this engraftment was not durable. It dropped to $0.1 \%$ by the age of 2 months and then $0.01 \%$ at 3 months. Moreover, the median level of chimerism decreased by 2 months of age to near undetectable levels. The level of chimerism at 1 month of age was not significantly different from that at 2 months $(\mathrm{p}=$ $0.109)$, but was significantly higher than that at 3 months $(p=0.008)$. These results indicate a transient engraftment by donor cells.

The recipients were sacrificed after 3-5 months for an analysis of chimerism in the various hematopoietic tissues and in the peritoneal cavity, the site of transplantation. The levels of donor cells in the spleen, bone marrow and peritoneal cavity were usually $\leq 0.05 \%$ (table 2 ). Remarkably, 1 mouse had $25.03 \%$ donor cells in its peritoneal cavity (fig. 3). This recipient also had higher levels of splenic chimerism (0.15\%). Additional examination of the peritoneal cells and splenocytes was performed for this recipient. The engrafted lineages included $\mathrm{B}$ cells $\left(\mathrm{CD} 19^{+}\right)$, myeloid cells $\left(\mathrm{Gr} 1^{+}\right)$and macrophages $\left(\mathrm{F} 4 / 80^{+}\right)$. The $\mathrm{Gr}^{+}$cells were mostly located in the area of low forward and side light scatter, suggesting that they might be immature progenitors or macrophages rather than granulocytes [32]. There was no evidence that $\mathrm{CD} 8^{+}$donor cells were present in either the spleen or peritoneal cavity at the time the animals were sacrificed.

\section{Analysis of T-Cell Tolerance}

At the time of sacrifice, the responses of $\mathrm{T}$ cells from the recipient mice were analyzed in mixed lymphocyte cultures (fig. 4). T-cell responses to splenocytes of donor, syngeneic and third-party origin were assessed. One recipient (No. 1) displayed T-cell-specific tolerance to donor cells. Its T cells proliferated in response to third-party stimulators but did not respond to donor stimulators. Three mice (No. 2-4) were hypo-responsive to donor cells, exhibiting significantly more T-cell proliferation to donor stimulators than to syngeneic stimulators but significantly less than to third-party stimulators. In 3 recipients (No. 5-7 as well as a control), T-cell proliferation to donor stimulators was not significantly different from that to third-party stimulators. These mice were considered to have a normal response comparable to untransplanted C57BL/6 mice. Two mice (No. 8, 9) had a hyper-response to donor stimulators. Their $\mathrm{T}$ cells proliferated more vigorously to the donor stimulators than to the third-party stimulators.

As the transplanted mice displayed a wide range of responses from tolerance to hyper-responsiveness, a link between tolerance and chimerism levels was sought by comparing the levels of chimerism in the different tissues between tolerant and non-tolerant mice (table 2). For simplicity, the T-cell responses in the mixed lymphocyte cultures are represented by a SI, which is calculated as described in the Materials and Methods. For these analy- 
Fig. 1. Flow cytometric analyses of chimerism levels in the peripheral blood in 1 recipient at 1 and 3 months of age. a These representative analyses include control samples stained with isotype-matched non-specific antibodies (bottom row) used to determine the levels of background staining. The levels of chimerism are determined by subtracting the frequency of non-specific events measured in the elliptic region from the frequency of specific events (top row). Accordingly, $0.23 \%$ chimerism was detected at 1 month of age and no evidence of chimerism was apparent by the 3rd month of age. b The dot plot of forward scatter vs. side scatter is gated by the live donor cells at 1 month of age in a. It shows that the donor cells comprise lymphoid and myeloid lineages.
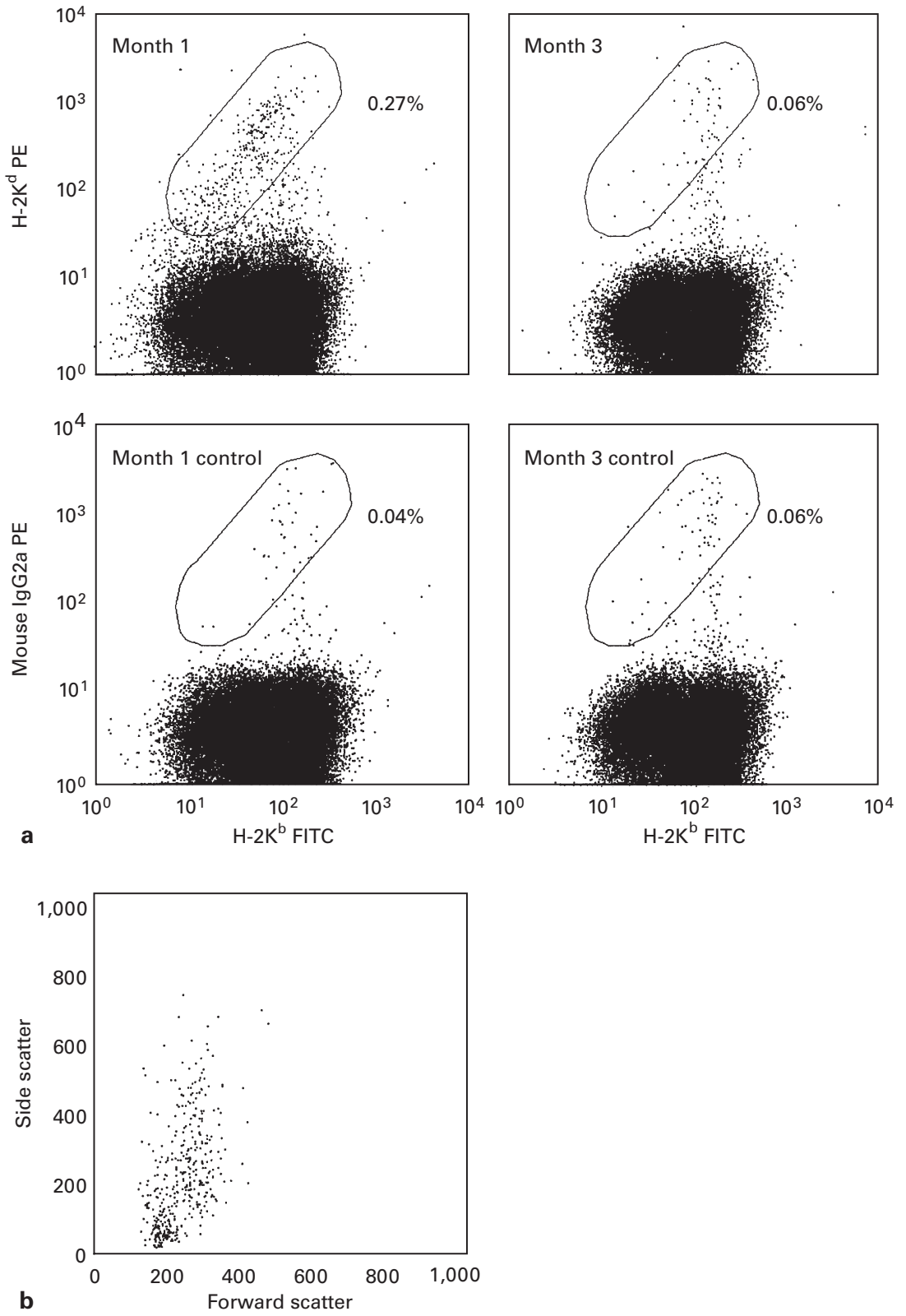

ses, tolerant animals included those animals that were deemed completely tolerant or hypo-responsive as described above. Non-tolerant mice included the remaining animals that had a normal response or were hyper-responsive. The tolerant mice had a significantly higher level of donor cells in the peritoneal cavity $(p=0.021)$. A bivariate correlation between SI and the level of peritoneal chi- 


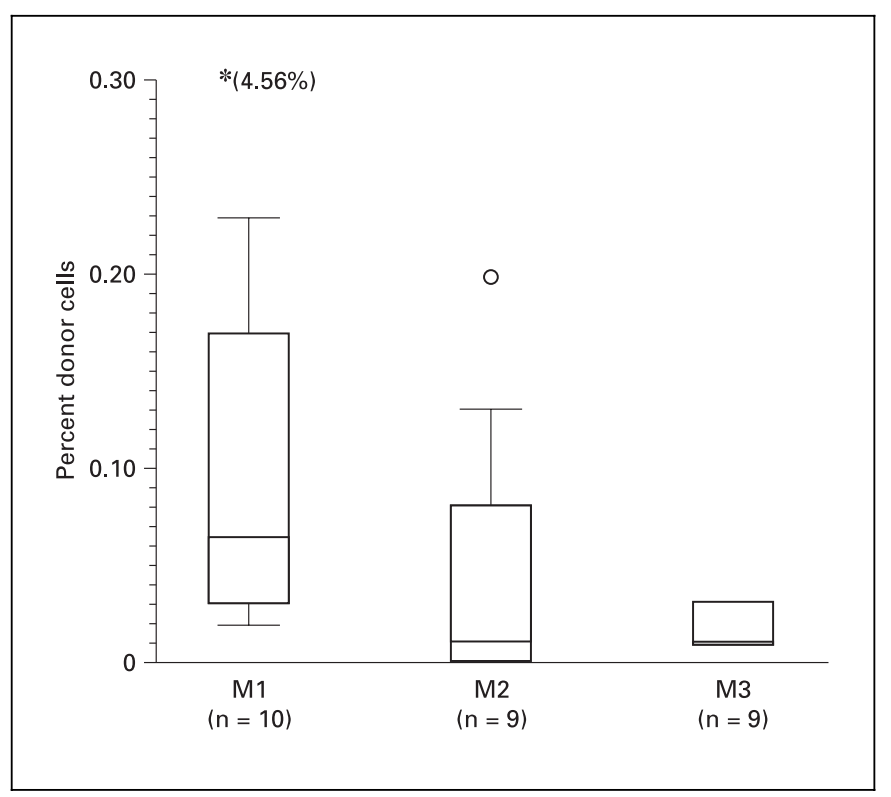

Fig. 2. Levels of donor cells in peripheral blood after IUT at the ages of 1, 2 and 3 months are shown. The presence of donor cells in the peripheral blood of recipients was measured by flow cytometry. Results are shown using box plots. The circle in the box plots indicates an outlying data point between 1.5 and 3 box lengths from the upper edge of the box. Another data point that falls beyond the scale is shown in parentheses.

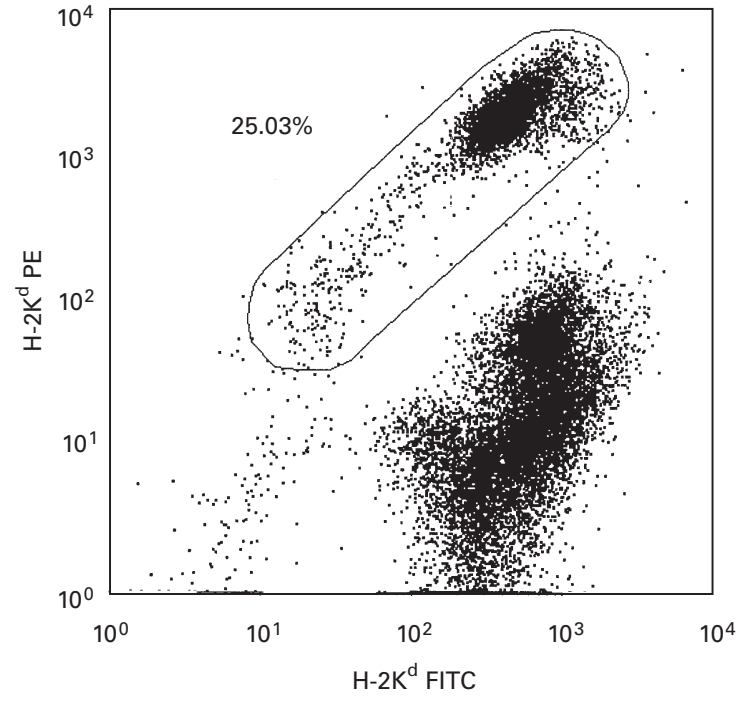

Fig. 3. Flow cytometric analyses of chimerism levels in the peritoneum of a transplanted mouse. The dot plot shows a chimerism level of $25.03 \%$ in the peritoneal cavity at the age of 3 months.
Fig. 4. Proliferative responses of recipient $T$ cells in MLRs. The number of daughter $\mathrm{CD}^{+} \mathrm{T}$ cells generated in response to syngeneic $(\mathrm{C} 57 \mathrm{BL} / 6)$, donor $\left(\mathrm{B} 6 \mathrm{D} 2 \mathrm{~F}_{1}\right)$ and third-party allogeneic $(\mathrm{FVB} / \mathrm{N})$ stimulators is shown. Recipient $(\mathrm{C})$ is an untransplanted C57BL/6 mouse used as a control. One of 10 recipients died by the age of 2 months and its MLR could not be measured. Data are shown as the mean \pm 2.0 SEM.

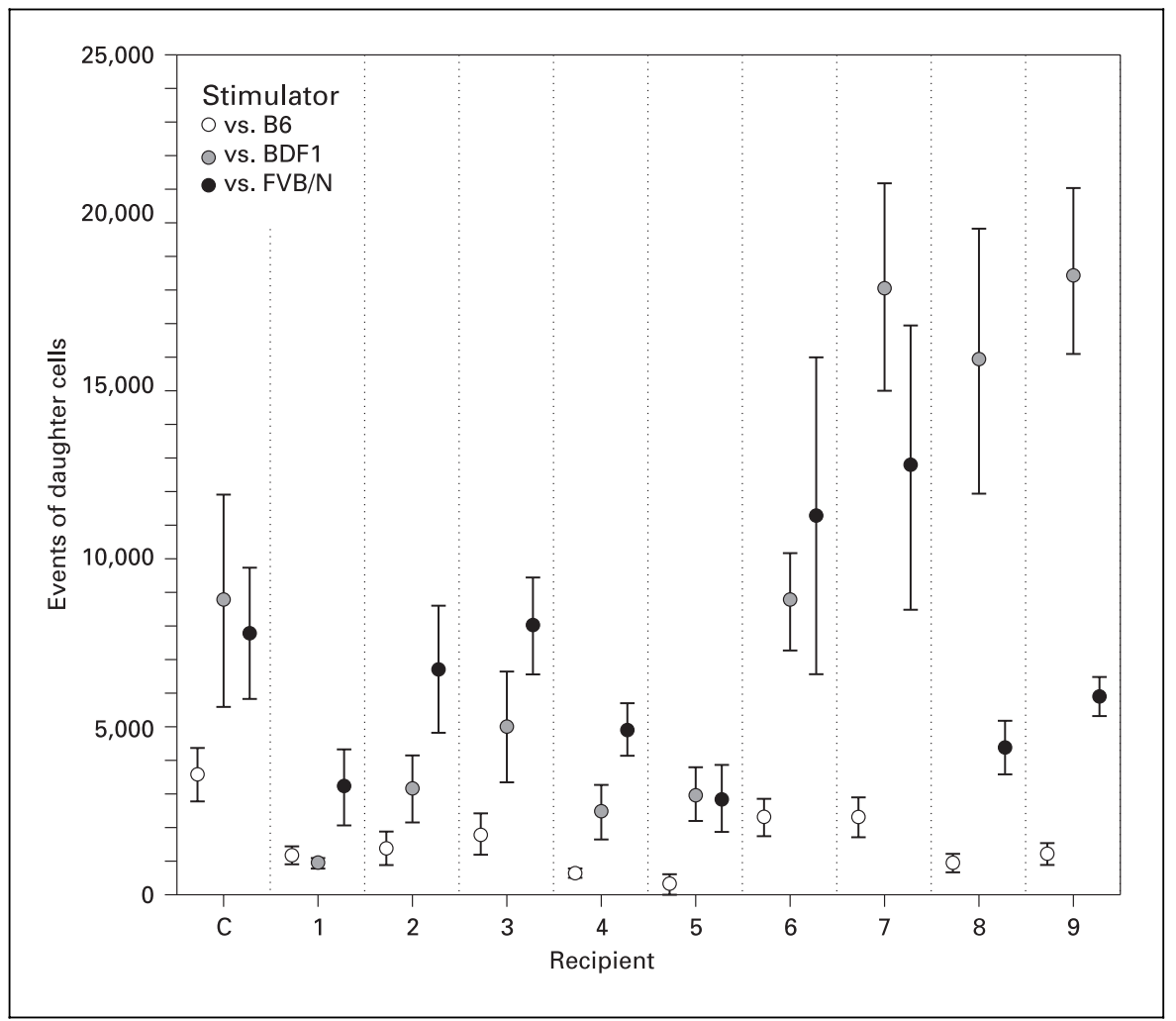

Chen/Chang/Lee/Muench 
Table 2. Chimerism levels in the spleens, bone marrow and peritoneal cavities of recipients sacrificed at 3-5 months of age

\begin{tabular}{|c|c|c|c|c|c|c|c|c|c|}
\hline & \multicolumn{9}{|c|}{ Mouse No. } \\
\hline & 1 & 2 & 3 & 4 & 5 & 6 & 7 & 8 & 9 \\
\hline Spleen & 0.04 & ND & 0.02 & 0.15 & ND & ND & ND & 0.02 & 0.02 \\
\hline $\mathrm{BM}$ & 0.01 & ND & ND & ND & 0.05 & 0.03 & 0.03 & 0.01 & ND \\
\hline Peritoneum & 0.60 & 0.03 & 0.05 & 25.03 & ND & 0.04 & ND & ND & ND \\
\hline SI & -0.11 & 0.34 & 0.51 & 0.43 & 1.07 & 0.71 & 1.52 & 4.35 & 3.69 \\
\hline
\end{tabular}

ND = None detected

\section{Discussion}

Successful induction of immunological tolerance to allogeneic donor cells by means of IUT would provide a new means of treatment for a potentially large number of birth defects. Some success has been reported using this approach, but results have not always been consistently favorable. Although the murine fetus before gestational day 17 is unable to mount an effective immunological attack against an allograft [33], a recent study has disclosed the possibility of in utero immunization to donor cells in mice [34]. Graft rejection was shown to occur following IUT as evidenced by accelerated skin graft rejection. It is possible that persistence of donor cells during the development of fetal immune system can sensitize the developing immune system to foreign cells rather than induce tolerance. Thus, graft rejection should be taken into consideration as one possible reason for graft failure following IUT. In this study, we tested if addition of Tc2 cells to bone marrow grafts can facilitate induction of donor-specific tolerance and/or engraftment. This study was modeled after a previous study demonstrating that Tc2 cells can dramatically facilitate engraftment following allogeneic postnatal BMT [28]. Our findings were mixed with tolerance induction occurring in only some instances. Although no clinically significant levels of bone marrow chimerism were observed, notable levels of chimerism were observed in the peritoneum, which correlated with the induction donor-specific T-cell tolerance.

Host T-cell responses to donor cells were found to be variable, ranging from complete tolerance to hyperresponsiveness. The most interesting finding was that tolerant or hypo-responsive recipients had significantly higher levels of donor cells in their peritoneal cavities. This was most clearly indicated by the inverse relationship between the SI and the level of peritoneal chimerism. What remains to be determined is whether the T-cell tol- erance observed was the result of lasting peritoneal chimerism or whether the peritoneal chimerism was the result of tolerance established early in development.

Chimerism in the spleen and bone marrow was very low or undetectable, even in the mice that were tolerant to donor cells. This observation suggests two conclusions. The first is that the donor cells in the peritoneal cavity are probably the result of local expansion of injected donor BMCs, rather than coming from the egress of donor cells from the bone marrow as a result of stem cell engraftment. This was most clearly indicated in the animal with the highest observed peritoneal chimerism of $25.03 \%$. Splenic chimerism in this animal was a much lower $0.15 \%$ and bone marrow chimerism was not detected. The second conclusion that can be drawn from our findings is that HSC engraftment in the bone marrow is prevented by more than just immunological rejection. This supports a favored hypothesis that HSC engraftment in fetuses, as in adults, is limited by the presence of the host's own hematopoietic cells $[1,10]$.

A graft-versus-host effect provided by donor $\mathrm{T}$ cells was reported to improve engraftment following IUT by generating available homing spaces [19]. Irradiation can also generate available homing spaces in the bone marrow, but is not a viable option for human prenatal transplantation. A notable difference between this study and the previous study of the effects of Tc2 cells on adult BMT was the use of a sublethal dose of irradiation prior to transplant [28]. Facilitation of engraftment by Tc2 cells has been attributed to a veto effect [35]. It relies upon that host precursor cytotoxic $\mathrm{T}$ lymphocytes, which are capable of mediating rejection, are deleted by the donor Tc2 cells. Thus, it is presumed that the veto effect of donor Tc2 cells aids in abrogating rejection, which in association with irradiation that further enables HSC engraftment, leads to a dramatic increase in chimerism. We only found a transient wave of donor cells in the peripheral blood at 
1 month of age with a subsequent drop of donor-cell levels to an insignificant level by the age of 3 months. This result is on a par with past reports [5-9]. Since the $F_{1}$-to-parent model we used does not permit a graft-versus-host effect by donor $\mathrm{T}$ cells, we can conclude that abrogating or alleviating rejection towards a graft alone is insufficient to increase HSC engraftment in the IUT setting. A recent report that used attenuated donor $T$ cells was successful in increasing engraftment with minimal GVHD [19]. Further studies of Tc2 cells in an allogeneic transplant model using methods to limit their graft-versus-host effect are warranted. The dose of Tc 2 cells transplanted also needs further evaluation, since higher numbers of Tc 2 cells may improve the incidence of tolerance inductions. There also remains the possibility for synergism between hematopoietic engraftment and transplanted Tc 2 cells in promot- ing tolerance induction. Selected subsets of $\mathrm{T}$ cells may yet provide a means to both improve engraftment as well as induce tolerance in the prenatal transplant setting.

\section{Acknowledgements}

We thank Rong-Hua Lu for his technical support in fetal injection, and Drs. Alicia Bárcena, Michael R. Harrison and Yuet-Wai Kan for their suggestions, helpful discussions and support. We also wish to thank Paul Dazin for assistance with flow cytometry. Thanks are further given to Drs. Akihiko Hara, KuoJen Tsao and Linda Flebbe-Rehwaldt for providing us with assistance in the care and breeding of mice.

This work was supported by grant NSC 93-2314-B-782A-086 (J.-C.C.) from the National Science Council, Taiwan and by NIH grant DK59301 (M.O.M.).

\section{References}

$>1$ Flake AW, Zanjani ED: In utero hematopoietic stem cell transplantation. A status report. JAMA 1997;278:932-937.

-2 Flake AW, Roncarolo MG, Puck JM, AlmeidaPorada G, Evans MI, Johnson MP, Abella EM, Harrison DD, Zanjani ED: Treatment of Xlinked severe combined immunodeficiency by in utero transplantation of paternal bone marrow. N Engl J Med 1996;335:1806-1810.

$\checkmark 3$ Muench MO, Bárcena A: Stem cell transplantation in the fetus. Cancer Control 2004;11:105118.

4 Zanjani ED, Pallavicini MG, Ascensao JL, Flake AW, Langlois RG, Reitsma M, MacKintosh FR, Stutes D, Harrison MR, Tavassoli M: Engraftment and long-term expression of human fetal hemopoietic stem cells in sheep following transplantation in utero. J Clin Invest 1992:89:1178-1188

$\checkmark 5$ Carrier E, Lee TH, Busch MP, Cowan MJ: Induction of tolerance in nondefective mice after in utero transplantation of major histocompatibility complex-mismatched fetal hematopoietic stem cells. Blood 1995;86:46814690.

6 Hajdu K, Tanigawara S, McLean LK, Cowan MJ, Golbus MS: In utero allogeneic hematopoietic stem cell transplantation to induce tolerance. Fetal Diagn Ther 1996;11:241-248.

$>7$ Milner R, Shaaban A, Kim HB, Fichter C, Flake AW: Postnatal booster injections increase engraftment after in utero stem cell transplantation. J Surg Res 1999;83:44-47.

$>8$ Kim HB, Shaaban AF, Yang EY, Liechty KW, Flake AW: Microchimerism and tolerance after in utero bone marrow transplantation in mice. J Surg Res 1998;77:1-5. $\checkmark 9$ Carrier E, Lee TH, Busch MP, Cowan MJ: Recruitment of engrafted donor cells postnatally into the blood with cytokines after in utero transplantation in mice. Transplantation 1997; 64:627-633.

10 Flake AW, Zanjani ED: In utero hematopoietic stem cell transplantation: Ontogenic opportunities and biologic barriers. Blood 1999;94: 2179-2191.

11 Muench MO, Rae J, Bárcena A, Leemhuis T, Farrell J, Humeau L, Maxwell-Wiggins JR, Capper J, Mychaliska GB, Albanese CT, Martin T, Tsukamoto A, Curnutte J, Harrison MR: Transplantation of a fetus with paternal Thy $-1^{+} \mathrm{CD} 34^{+}$cells for chronic granulomatous disease. Bone Marrow Transplant 2001;27: 355-364.

12 Martin PJ: Determinants of engraftment after allogeneic marrow transplantation. Blood 1992;79:1647-1650.

13 Martin PJ, Hansen JA, Torok-Storb B, Durnam D, Przepiorka D, O'Quigley J, Sanders J, Sullivan KM, Witherspoon RP, Deeg HJ, et al: Graft failure in patients receiving $\mathrm{T}$ cell-depleted HLA-identical allogeneic marrow transplants. Bone Marrow Transplant 1988;3:445456.

14 Martin PJ, Hansen JA, Buckner CD, Sanders JE, Deeg HJ, Stewart P, Appelbaum FR, Clift $\mathrm{R}$, Fefer A, Witherspoon RP, et al: Effects of in vitro depletion of T cells in HLA-identical allogeneic marrow grafts. Blood 1985;66:664-672.

15 Kernan NA, Collins NH, Juliano L, Cartagena T, Dupont B, O'Reilly RJ: Clonable T lymphocytes in $\mathrm{T}$ cell-depleted bone marrow transplants correlate with development of graft-vs.host disease. Blood 1986;68:770-773.

$>16$ Korngold R, Sprent J: Surface markers of T cells causing lethal graft-vs.-host disease to class I vs. class II H-2 differences. J Immunol 1985;135:3004-3010.
17 Shields LE, Andrews RG: In utero stem cell transplantation in non-human primates: The role of T-cells number (abstract). Am J Obstet Gynecol 2001;184:S2.

18 Crombleholme TM, Harrison MR, Zanjani ED: In utero transplantation of hematopoietic stem cells in sheep: The role of $\mathrm{T}$ cells in engraftment and graft-versus-host disease. J Pediatr Surg 1990;25:885-892.

19 Bhattacharyya S, Chawla A, Smith K, Zhou Y, Talib S, Wardwell B, Cowan MJ: Multilineage engraftment with minimal graft-versus-host disease following in utero transplantation of s59 psoralen/ultraviolet a light-treated, sensitized $\mathrm{T}$ cells and adult $\mathrm{T}$ cell-depleted bone marrow in fetal mice. J Immunol 2002;169: 6133-6140.

20 Martin PJ: Donor CD8 cells prevent allogeneic marrow graft rejection in mice: Potential implications for marrow transplantation in humans. J Exp Med 1993;178:703-712.

21 Palathumpat V, Dejbakhsh-Jones S, Strober S: The role of purified $\mathrm{CD} 8^{+} \mathrm{T}$ cells in graft-versus-leukemia activity and engraftment after allogeneic bone marrow transplantation. Transplantation 1995;60:355-361.

22 Martin PJ, Rowley SD, Anasetti C, Chauncey TR, Gooley T, Petersdorf EW, van Burik JA, Flowers ME, Storb R, Appelbaum FR, Hansen JA: A phase I-II clinical trial to evaluate removal of CD4 cells and partial depletion of CD8 cells from donor marrow for HLA-mismatched unrelated recipients. Blood 1999;94: 2192-2199.

23 Martin PJ, Akatsuka Y, Hahne M, Sale G: Involvement of donor T-cell cytotoxic effector mechanisms in preventing allogeneic marrow graft rejection. Blood 1998;92:2177-2181. 
24 Gandy KL, Domen J, Aguila H, Weissman IL: $\mathrm{CD}^{+} \mathrm{TCR}^{+}$and $\mathrm{CD}^{+}{ }^{+} \mathrm{TCR}^{-}$cells in whole bone marrow facilitate the engraftment of hematopoietic stem cells across allogeneic barriers. Immunity 1999;11:579-590.

25 Sad S, Marcotte R, Mosmann TR: Cytokineinduced differentiation of precursor mouse $\mathrm{CD}^{+} \mathrm{T}$ cells into cytotoxic $\mathrm{CD} 8^{+} \mathrm{T}$ cells secreting Th1 or Th2 cytokines. Immunity 1995;2: 271-279.

26 Croft M, Carter L, Swain SL, Dutton RW Generation of polarized antigen-specific CD 8 effector populations: Reciprocal action of interleukin (IL)-4 and IL-12 in promoting type 2 versus type 1 cytokine profiles. J Exp Med 1994; 180:1715-1728.

-27 Fowler DH, Gress RE: CD8 ${ }^{+} \mathrm{T}$ cells of Tc2 phenotype mediate a GVL effect and prevent marrow rejection. Vox Sang 1998;74:331-340.
28 Fowler DH, Whitfield B, Livingston M, Chrobak P, Gress RE: Non-host-reactive donor $\mathrm{CD}^{+} \mathrm{T}$ cells of $\mathrm{Tc} 2$ phenotype potently inhibit marrow graft rejection. Blood 1998;91:40454050.

29 Fowler DH, Breglio J, Nagel G, Eckhaus MA, Gress RE: Allospecific CD8 ${ }^{+} \mathrm{Tc} 1$ and Tc2 populations in graft-versus-leukemia effect and graft-versus-host disease. J Immunol 1996;157: 4811-4821.

30 Fowler DH, Gress RE: Th2 and Tc2 cells in the regulation of GVHD, GVL, and graft rejection: Considerations for the allogeneic transplantation therapy of leukemia and lymphoma. Leuk Lymphoma 2000;38:221-234.

31 Chen JC, Chang ML, Muench MO: A kinetic study of the murine mixed lymphocyte reaction by 5,6-carboxyfluorescein diacetate succinimidyl ester labeling. J Immunol Meth 2003;279: 123-133.
32 Hestdal K, Ruscetti FW, Ihle JN, Jacobsen SEW, Dubois CM, Kopp WC, Longo DL, Keller JR: Characterization and regulation of RB6$8 \mathrm{C} 5$ antigen expression on murine bone marrow cells. J Immunol 1991;147:22-28.

33 Defresne MP, Humblet C, Deman J, et al: Ontogeny of T-cell surface molecules and receptors in the thymus. Prog Histochem Cytochem 1992;26:194-200.

34 Donahue J, Gilpin E, Lee TH, Busch MP, Croft M, Carrier E: Microchimerism does not induce tolerance and sustains immunity after in utero transplantation. Transplantation 2001;71: 359-368.

35 Hiruma K, Nakamura H, Henkart PA, Gress RE: Clonal deletion of postthymic T cells: Veto cells kill precursor cytotoxic T lymphocytes. J Exp Med 1992;175:863-868. 